\title{
Laboratory feeding experiments on zoea of northern shrimp Pandalus borealis fed with natural zooplankton
}

\author{
Michel Harvey*, Guylaine Morrier \\ Direction des Sciences Océaniques, Ministère des Pêches et des Océans, Institut Maurice-Lamontagne, CP 1000, Mont-Joli, \\ G5H $3 Z 4$ Québec, Canada
}

\begin{abstract}
A series of experiments was carried out in spring 2001 and 2002 in order to investigate the effects of prey concentration, prey type and size, predator life stage, predator starvation, and temperature on predation rates of larvae of the northern shrimp Pandalus borealis reared in the laboratory. Stage IV shrimp larvae that were offered a natural zooplankton assemblage showed a significant trend of linearly increasing predation over the full range of 3 to 250 prey $\mathrm{l}^{-1}$. This followed the Holling type I functional response model. Individual Stage IV shrimp larvae ingested up to 14 prey $\mathrm{d}^{-1}$ at the highest initial prey concentration offered (250 prey $\left.\mathrm{l}^{-1}\right)$. Temperature effects were investigated with Stage II shrimp larvae as predators. The predation rate increased significantly, from 11 (at $3^{\circ} \mathrm{C}$ ) to 21 (at $5^{\circ} \mathrm{C}$ ) prey per predator $\mathrm{d}^{-1}$, but stayed stable at 24 prey per predator $\mathrm{d}^{-1}$ at $8^{\circ} \mathrm{C}$. The majority of the prey eaten by the Stage II shrimp larvae were small (copepod nauplii; other invertebrate eggs and nauplii) while those eaten by the Stage IV larvae were larger (Calanus finmarchicus CI, CII, CIII and body parts of CIV, CV, CVI). However, Stage IV larvae also ate small prey (copepod eggs and nauplii, other invertebrate nauplii).
\end{abstract}

KEY WORDS: Pandalus borealis - Predation rate - Gulf of St. Lawrence · Decapod larvae • Zooplankton $\cdot$ Feeding experiment $\cdot$ Starvation

Resale or republication not permitted without written consent of the publisher

\section{INTRODUCTION}

The eastern Canadian northern shrimp Pandalus borealis fishery increased substantially in the 1990s in response to a general increase in abundance and biomass levels (Savard et al. 2002). Even through the standing stock and potential yield are scientifically assessed each year, forecasting of stock productivity is still problematic. This is largely due to a lack of detailed knowledge concerning recruitment processes and mechanisms responsible for variations in growth and abundance of younger stages (see Bergström 2000).

Pandalus borealis larvae hatch as fully developed zoea capable of swimming and active feeding (Stickney \& Perkins 1981). Therefore, food quality and quantity are key determinants for their survival and development (Shumway et al. 1985, Ouellet et al. 1995, Bergström 2000, Anger 2001). Detailed information on the feeding characteristics, including ingestion rate and food selectivity in relation to changing environmental conditions (temperature, salinity), food availability, developmental stage, and the state of hunger, is required to predict the survival probability of larvae during the first year and the cohort strength in subsequent years (Anger 2001). Because of its importance, the nutrition factor has received special attention in literature on crustaceans over the past 2 decades (see review in Anger 2001). Nevertheless, most studies have dealt with the culture of commercially exploitable species and have been directed towards the aquaculture-related aspect of nutrition (development of artificial feeds) rather than the study of a better understanding of the trophic role of decapod crustacean larvae (Anger 2001). For Pandalus larvae in particular, very few studies have examined the nutritional aspects under natural conditions (see review in Bergström 2000). Paul et al. (1979) observed the daily consump- 
tion rates of copepods by studying the larvae of 3 crustaceans, including $P$. borealis, while Lebour (1922) and Stickney \& Perkins (1981) examined the intestinal tracts of larval $P$. borealis from plankton tows and listed the various items found. However, the ingestion rate and selection of sympatric prey in relation to changing environmental conditions (temperature, salinity), food availability, developmental stage, and the state of hunger have never been examined. The purpose of the present study was to investigate aspects of predatory feeding by $P$. borealis larvae fed with a natural zooplankton assemblage under varying conditions. These aspects include the relationship between predation rates and (1) prey concentrations, (2) prey type and size, (3) temperature, (4) predator size (life history stage), and (5) predator starvation.

\section{MATERIALS AND METHODS}

Collection and handling of larvae. Gravid females of the northern shrimp Pandalus borealis were captured between 20 and 30 April 2001 and 2002 in the Lower St. Lawrence Estuary $\left(48.67^{\circ} \mathrm{N}, 68.59^{\circ} \mathrm{W}\right)$. They were carried live to the laboratory and acclimatized in a large holding tank (2500 l) in the dark at a constant temperature of $2^{\circ} \mathrm{C}$ for about $15 \mathrm{~d}$. After this period, 15 females in good condition were transferred into five 80 l plankton-kreisel rearing tanks (3 females per tank) and incubated for $3 \mathrm{~d}$ at $5^{\circ} \mathrm{C}$. Females were retrieved when ca. 1000 newly hatched shrimp larvae were observed in each tank. From the day after hatching, shrimp larvae were fed daily with freshly hatched Artemia sp. (San Francisco brand) nauplii and kept in the $80 \mathrm{l}$ plankton-kreisel tanks at $5^{\circ} \mathrm{C}$ with a $16: 8 \mathrm{~h}$ light:dark cycle.

Measurement of feeding rates. All feeding experiments were carried out using a natural zooplankton prey assemblage except for the predator life stage experiments and 2 predator starvation experiments. Prey zooplankton were collected fresh for each experiment with a $73 \mu \mathrm{m}$ mesh net with a nonfiltering cod end, using slow (ca. 0.2 to $0.4 \mathrm{~m} \mathrm{~s}^{-1}$ ) vertical hauls from approximately $50 \mathrm{~m}$ depth. The material was fractionated into 2 size categories $(<1000$ and $\geq 1000 \mu \mathrm{m})$ by gently pouring the sample through a $1000 \mu \mathrm{m}$ screen, always keeping the animals in water. Only the small size fraction $(<1000 \mu \mathrm{m})$ was kept as the experimental prey population. The average gross composition of this experimental prey population (in numbers) was 58\% copepods, $29 \%$ copepod and other invertebrate eggs, $10 \%$ invertebrate larvae and copepod nauplii, and $3 \%$ others. The average gross composition of the copepods was $80 \%$ Calanus finmarchicus, $12 \%$ Oithona similis, $5 \%$ Metridia longa, and 2\% Pseudocalanus spp.
The experiments were conducted in 11 plastic bottles filled with $0.2 \mu \mathrm{m}$-filtered seawater and placed in a cold room at $5^{\circ} \mathrm{C}$ for about $48 \mathrm{~h}$ before the experiments. Pandalus borealis larvae of the same stage of maturity were transferred into bottles (5 per bottle) without food for about $24 \mathrm{~h}$ before the experiments. The larval stages were determined following the description of Haynes (1979). Within $2 \mathrm{~h}$ of capture, the experimental prey population was concentrated into a 201 container to obtain ca. 1 organism $\mathrm{ml}^{-1}$. To prepare the experimental prey concentrations, the water in the zooplankton container was carefully stirred and exact volumes (between 5 and $300 \mathrm{ml}$ ) of water (and zooplankton) were extracted with a Stempel pipette and added to the 11 plastic bottles already containing the shrimp larvae. The bottles were filled and sealed with plastic film to prevent air bubbles, placed on a plankton wheel, and rotated at $0.5 \mathrm{rpm}$ for $24 \mathrm{~h}$. The experiments were always started in the morning. Shrimp larvae and zooplankters that remained in the bottles after the experiment were preserved in $4 \%$ buffered formaldehyde. Later, the entire sample was examined using a binocular microscope to determine the species composition and abundance of all zooplankters, including adult copepods and copepodite stages.

Expt 1-effects of prey concentration, prey type, and prey size. The effects of the prey concentration, prey type, and prey size were investigated with a typical functional response experiment in May 2001 using Stage IV shrimp larvae as the predators. In this experiment, we used 8 prey densities of ca. 3, 7, 15, 24, 40, 82,166 , and 250 prey $\mathrm{l}^{-1}$. Three replicates of each prey concentration were distributed randomly into 24 plastic bottles (1 l) that had contained the shrimp larvae for $24 \mathrm{~h}$. Two additional replicates of each concentration were also preserved immediately for estimates of the initial zooplankton abundance. In addition, 3 predatorfree replicates of ca. 200 prey $\mathrm{l}^{-1}$ were used as controls to estimate the mortality caused by other factors than predation by shrimp larvae. Both experimental and control bottles were filled, sealed with a plastic film, and placed horizontally on the plankton wheel. The diet composition and the predation rates were determined from the difference in the prey composition and abundance before and after exposure to the predator. Examination of the first samples showed that some of the larger copepods had been partly eaten. These animals were considered as totally eaten in the calculation of the predation rate.

Expt 2-effects of temperature. The temperature effects were investigated in May 2001 with Stage II shrimp larvae as the predators. Three different feeding experiments were carried out simultaneously in 3 cold rooms set at 3,5 , and $8^{\circ} \mathrm{C}$. In each cold room, we used 5 experimental replicates with ca. 250 prey $\mathrm{l}^{-1}$ and 3 
predator-free control replicates containing the same prey density. Bottles were filled, sealed with plastic film, then placed on a shelf for $24 \mathrm{~h}$ with a 16:8 h light: dark cycle. The bottles were not rotated for this experiment because only 1 plankton wheel was available. For each temperature, the diet composition and the predation rates were determined from the difference in the prey composition and abundance in replicates exposed and not exposed to predators.

Expt 3-effects of predator starvation. Three different feeding experiments were carried out to investigate the effect of predator starvation on the diet composition and the predation rates of the shrimp larvae. The first experiment was carried out in May 2001 with Stage II shrimp larvae as the predator and natural zooplankton as prey. Five shrimp larvae were transferred into five 11 plastic bottles, without food, for about 72, 48 , and $24 \mathrm{~h}$ before the beginning of the experiment. On the day of the experiment, a solution of ca. 70 prey $^{-1}$ was transferred into each of the 15 experimental replicates ( 5 replicates per starvation period); 3 predatorfree control replicates also containing ca. 70 prey $\mathrm{l}^{-1}$ were prepared. Both experimental and control bottles were filled and sealed with plastic film, placed horizontally on a plankton wheel, and rotated at $0.5 \mathrm{rpm}$ for $24 \mathrm{~h}$ in a cold room at $5^{\circ} \mathrm{C}$.

The second and the third experiments on the effect of predator starvation were carried out in May 2002 with Stage II and IV shrimp larvae as the predators and freshly hatched Artemia sp. nauplii as prey. These experiments were conducted to confirm the results obtained with the natural zooplankton prey assemblage during the previous year. The 2 experiments were conducted at $3 \mathrm{wk}$ intervals using the same protocol as in spring 2001, except that the prey concentration in each bottle was ca. 150 prey $\mathrm{l}^{-1}$ and the incubation period was $6 \mathrm{~h}$. This shorter incubation period for experiments using freshly hatched Artemia sp. nauplii as prey was chosen as the most appropriate according to preliminary experiments with durations of $2,4,6$, and $24 \mathrm{~h}$ (see next paragraph).

Expt 4-effects of predator life stage. Six different feeding experiments were carried out to investigate the effect of predator life stage on the predation rates of the shrimp larvae. These experiments were conducted during a period of $8 \mathrm{wk}$ in May and June 2002 with Stage I, II, III, IV, V, and VI larvae as predators and freshly hatched Artemia sp. nauplii as prey. We used Artemia sp. to replace the natural zooplankton assemblage because it is nearly impossible to obtain shrimp larvae of 6 different life stages at the same time and, therefore, to conduct 6 feeding experiments simultaneously with the same natural zooplankton assemblage. The 6 experiments were carried out following the same protocol as the previous experiments using Artemia sp., except that 12 experimental and 3 control replicates were used in each experiment. The controls were preserved at the beginning of the experiment and used for estimates of the initial abundance of Artemia sp. The experiment was stopped by groups of 3 replicates after $2,4,6$, and $24 \mathrm{~h}$ of incubation in order to identify the most appropriate incubation time for each life stage and to obtain a clear predation signal without the prey being completely depleted before the end of the incubation.

Data analysis. The initial number of prey in Expt 1 was estimated using a linear regression between both the volume and the total abundance of prey in the 2 replicates of each concentration that was preserved at the beginning of the experiment. Furthermore, for the 200 prey $^{-1}$ concentration, mortality caused by factors other than predation by shrimp larvae was estimated by comparing the abundance of each prey species with the 2 replicates preserved at the beginning of the experiment and with the 3 predator-free controls of the same density using Student's $t$-tests on $\log _{10}$-transformed data. For each prey item showing a significant difference, this difference was expressed as a percentage and used as a correction factor to estimate the initial number of prey at each concentration. Thereafter, the feeding rates ( $F R_{i}$ prey per predator per $24 \mathrm{~h}$ ) for each concentration were calculated as:

$$
\mathrm{FR}=\left(N_{\mathrm{i}}-N_{\mathrm{f}}\right) / n t \times 24
$$

where $N_{\mathrm{i}}=$ initial number of prey, $N_{\mathrm{f}}=$ final number of prey, $n=$ number of predators, and $t=$ incubation time (h).

Finally, we used Student's $t$-tests or 1-way ANOVA models followed by Tukey pairwise comparison tests on significant results to test for differences in feeding rates between treatments in all experiments (functional response, predator life stage, predator starvation, and temperature). These analyses were performed on $\log _{10}$-transformed data.

\section{RESULTS}

\section{Expt 1 -effects of prey concentration}

According to the Student's $t$-tests comparing the mean abundance of each prey item at the beginning and the end of the incubation in the 3 predator-free control replicates $\left(200\right.$ prey $\left.^{-1}\right)$, only copepod eggs showed a significant difference at the end of the incubation period $\left(t_{(3)}=\right.$ $8.073 ; \mathrm{p}=0.000$ ). This difference represents a decrease of $63.5 \%$ and was used as a correction factor to estimate the initial number of copepod eggs in each concentration as well as the total prey abundance. 


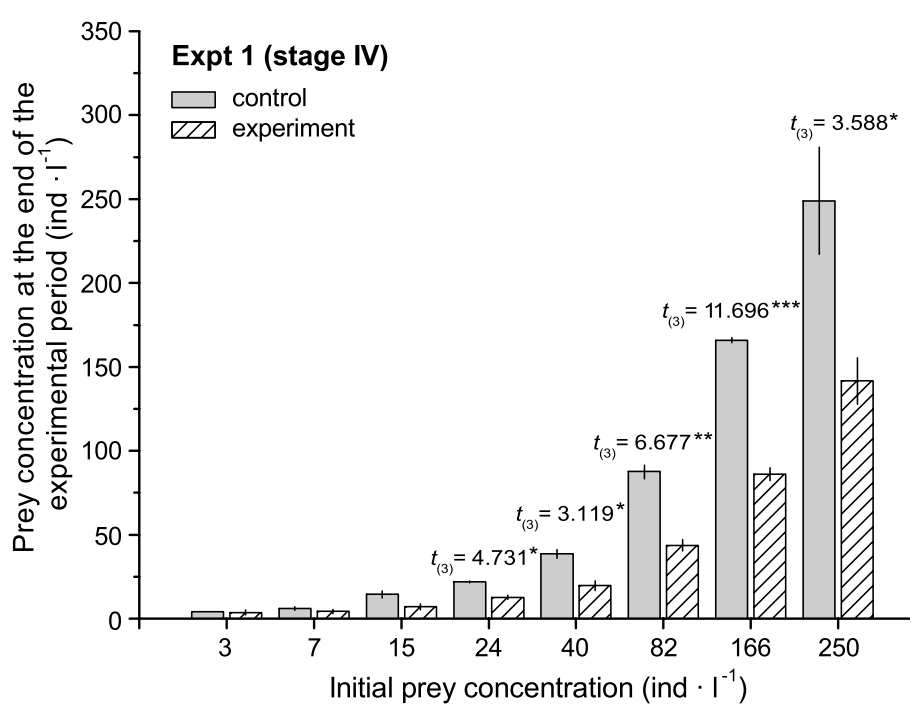

Fig. 1. Pandalus borealis. Mean $( \pm \mathrm{SE})$ prey concentrations in control and experimental treatments for 8 initial prey concentrations varying from 3 to 250 prey $\mathrm{l}^{-1}$. Results from Student's $t$-tests comparing the mean abundance between the control and the experimental treatments are also shown $\left({ }^{*} p \leq 0.05\right.$, $\left.{ }^{* *} \mathrm{p} \leq 0.01,{ }^{* * *} \mathrm{p} \leq 0.001\right)$

Fig. 1 shows the mean prey concentration in the control and experimental treatments for 8 initial prey concentrations varying from 3 to 250 prey $^{-1}$. Stage IV shrimp larvae that were offered a natural zooplankton assemblage showed a statistically significant trend $\left(\mathrm{r}^{2}=0.955, \mathrm{p}<0.001\right)$ of linearly increasing predation over the full range of 3 to 250 prey l$^{-1}$ (Fig. 2). This followed the Holling type I functional response model. The impact of predation by the shrimp larvae was significant at prey concentrations $\geq 24$ prey $\mathrm{l}^{-1}$ (Fig. 1). Individual Stage IV shrimp larvae ingested up to $13.55 \pm 1.73$ prey per predator $\mathrm{d}^{-1}$ (mean $\left.\pm \mathrm{SE}\right)$ at the

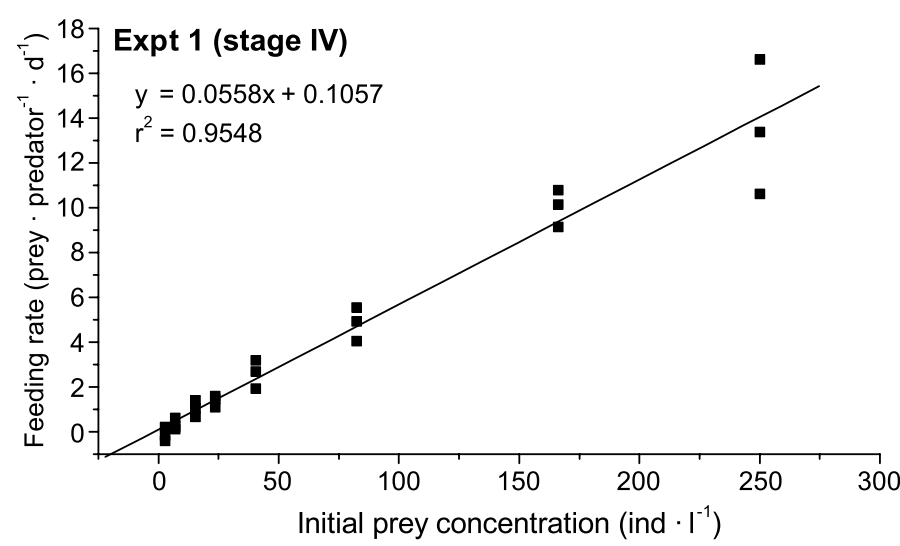

Fig. 2. Pandalus borealis. Feeding rate of Stage IV shrimp larvae fed with different natural zooplankton densities. Data were fitted with the Holling type I equation highest initial prey concentration offered (250 prey $\left.\mathrm{l}^{-1}\right)$.

Fig. 3 shows the mean prey concentration in the control and experimental treatments at 8 initial prey concentrations for 7 different types of prey found in the natural zooplankton assemblage. As found for the total prey abundance, the impact of predation by the shrimp larvae on the different zooplankton species and/or categories was significant at prey concentrations $\geq 24$ prey $^{-1}$ and increased as a function of the initial prey concentration (Fig. 3). The impact of predation by the Stage IV shrimp larvae was significant in both smaller (copepod eggs, copepod nauplii, invertebrate nauplii) and larger (Calanus finmarchicus copepodite Stages I, II, and III) zooplankton prey (Figs. 3 \& 4).

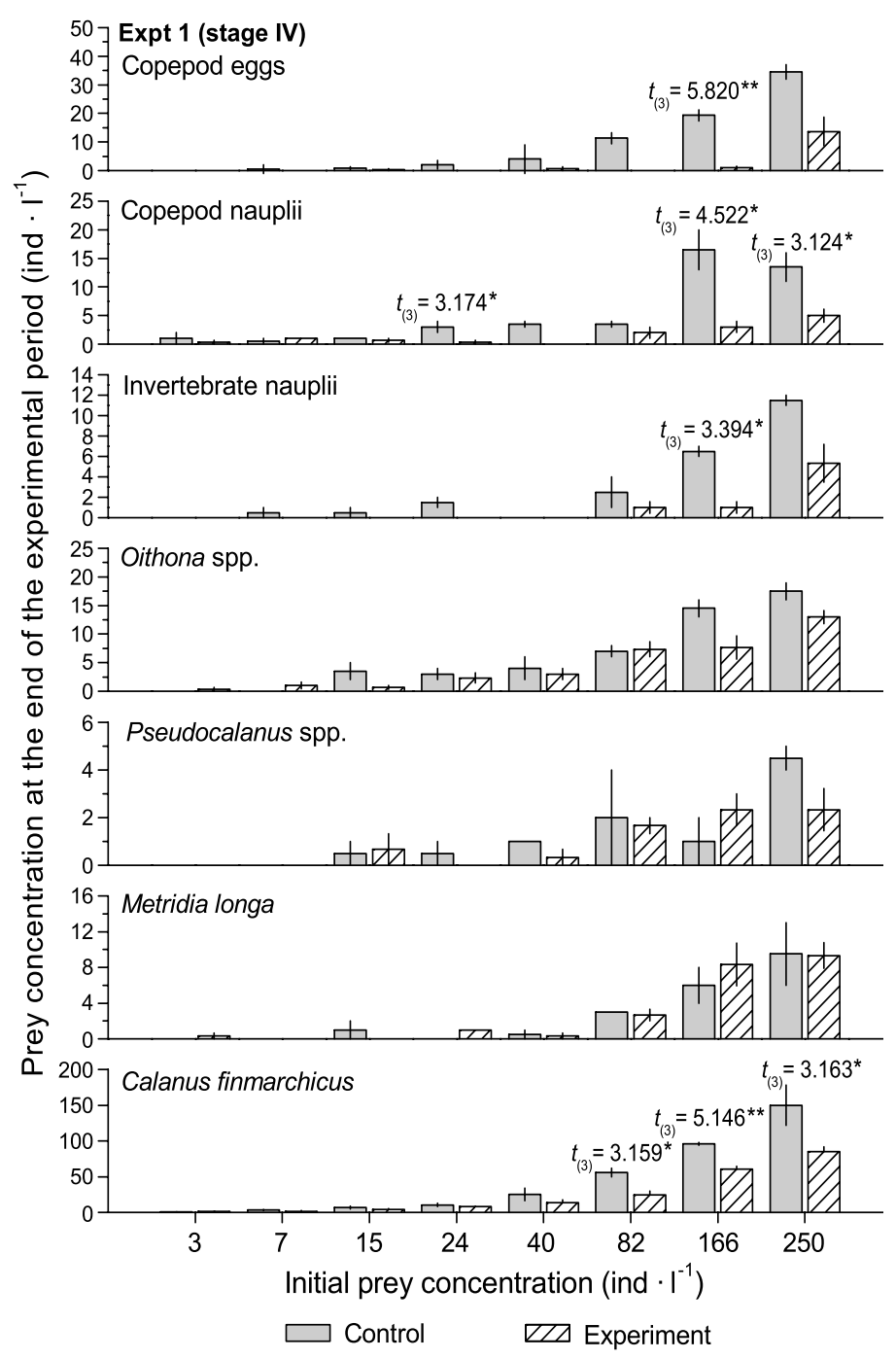

Fig. 3. Pandalus borealis. Mean $( \pm \mathrm{SE})$ prey concentrations of different zooplankton species and categories in control and experimental treatments for 8 initial prey concentrations varying from 3 to 250 prey $\mathrm{l}^{-1}$. Results of Student's $t$-tests comparing the mean abundance between the control and the experimental treatments are also shown $\left({ }^{*} \mathrm{p} \leq 0.05,{ }^{* *} \mathrm{p} \leq 0.01,{ }^{* * *} \mathrm{p} \leq 0.001\right)$ 


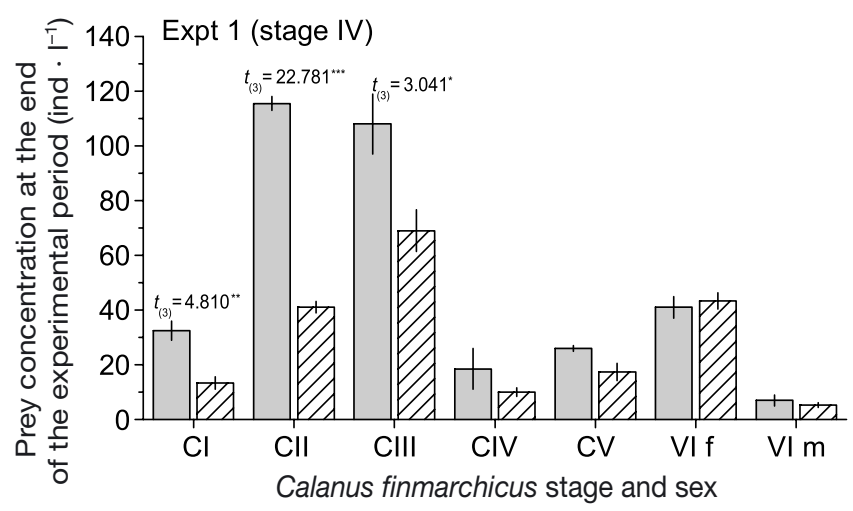

Fig. 4. Pandalus borealis. Mean $( \pm \mathrm{SE})$ concentrations of different copepodite stages of Calanus finmarchicus in control and experimental treatments. Results of the Student's $t$-tests comparing the mean abundance between the control and the experimental treatments are also shown $\left({ }^{*} \mathrm{p} \leq 0.05,{ }^{* *} \mathrm{p} \leq 0.01,{ }^{* * *} \mathrm{p} \leq 0.001\right)$

\section{Expt 2-effects of temperature}

Results of the Student's $t$-tests showed that the treatment (control vs experiment) had significant effects on the total prey concentration in experiments carried out at 3,5 , and $8^{\circ} \mathrm{C}$ (Fig. 5). The predation rate increased significantly from $10.94 \pm 2.08$ to $20.46 \pm 1.12$ prey per predator $\mathrm{d}^{-1}$ when temperature increased from 3 to $5^{\circ} \mathrm{C}$, but did not differ significantly at 8 and $5^{\circ} \mathrm{C}$ (Fig. 6). The small-sized prey (invertebrate eggs and nauplii, copepod nauplii, Oithona spp.) predominantly displayed a significant predation effect, although some larger prey were also eaten (copepodite Stages I to III and Calanus finmarchicus CI to IV) (Fig. 5). As with total prey abundance, the predation rate increased significantly between 3 and $5^{\circ} \mathrm{C}$ and remained stable at $8^{\circ} \mathrm{C}$ in each of the 3 prey categories favored by shrimp larvae (invertebrate eggs and nauplii, copepod nauplii) (Fig. 6).

\section{Expt 3-effects of predator starvation}

The ANOVA results showed that treatment (experiment vs control) displayed a significant effect on the prey concentration (prey $\mathrm{l}^{-1}$ ) in each of the 3 experiments carried out with shrimp larvae that did not receive food for 24 , 48 , or $72 \mathrm{~h}$ before the beginning of the experiment (Fig. 7). There was no significant difference between the prey concentrations for the 3 periods tested or between the predation rates
(Fig. 7). Likewise, the results of the experiments carried out in May 2002 with Stage II and IV shrimp larvae as the predator and freshly hatched Artemia sp. nauplii as prey showed the same result. Treatment had a significant effect (experiment vs control) on prey concentration (prey $\mathrm{l}^{-1}$ ) in each of the 3 periods of starvation tested, but the period of starvation displayed no significant effect on the prey concentration or on the predation rate (Fig. 7).
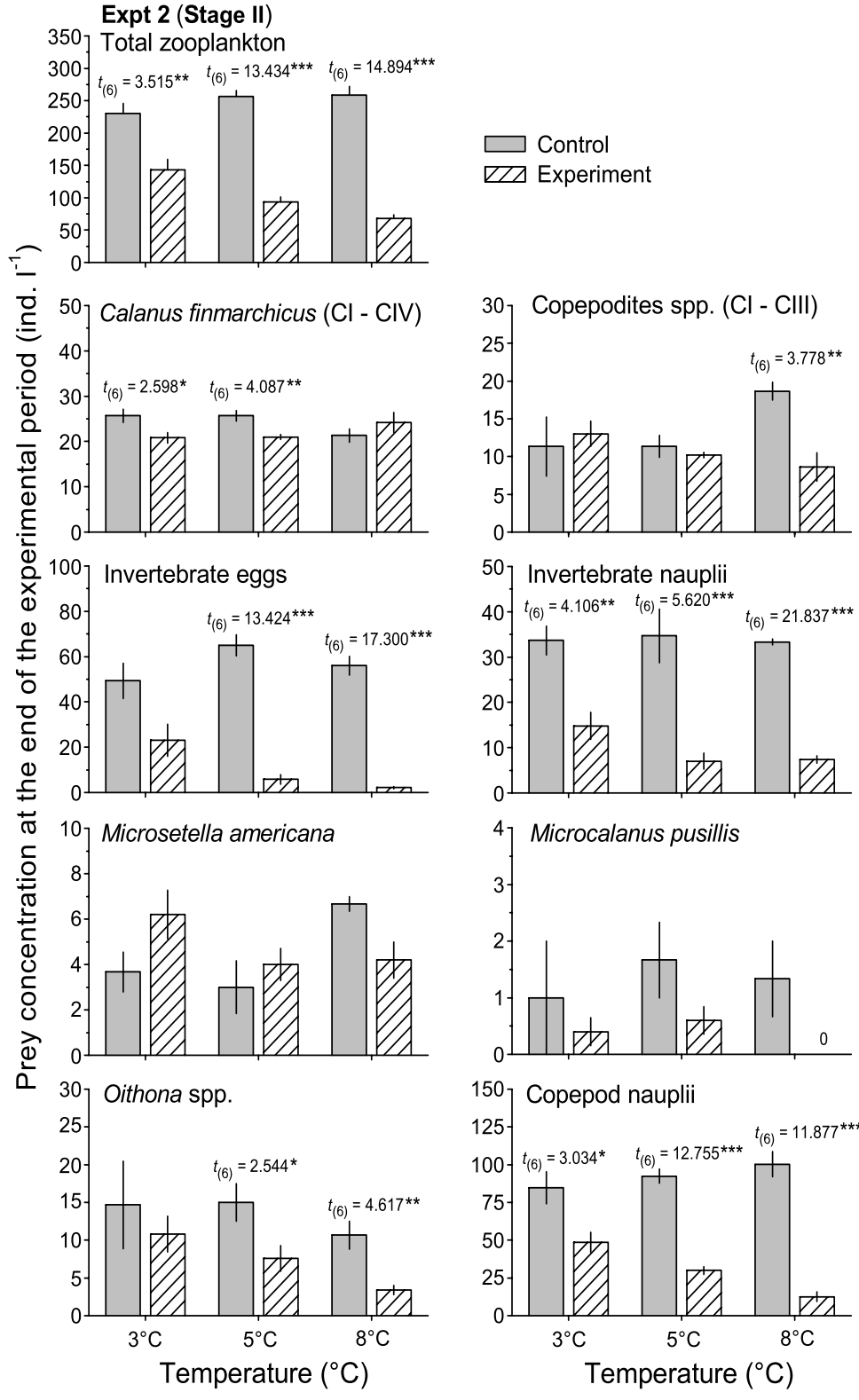

Fig. 5. Pandalus borealis. Mean $( \pm \mathrm{SE})$ prey concentrations of different zooplankton species and categories in control and experimental treatments from experiments carried out at 3,5 , and $8^{\circ} \mathrm{C}$ respectively. Results of the Student's $t$-tests comparing the mean abundance between the control and the experimental treatments are also shown $\left({ }^{*} p \leq 0.05,{ }^{* *} p \leq 0.01,{ }^{* * *} p \leq 0.001\right)$ 


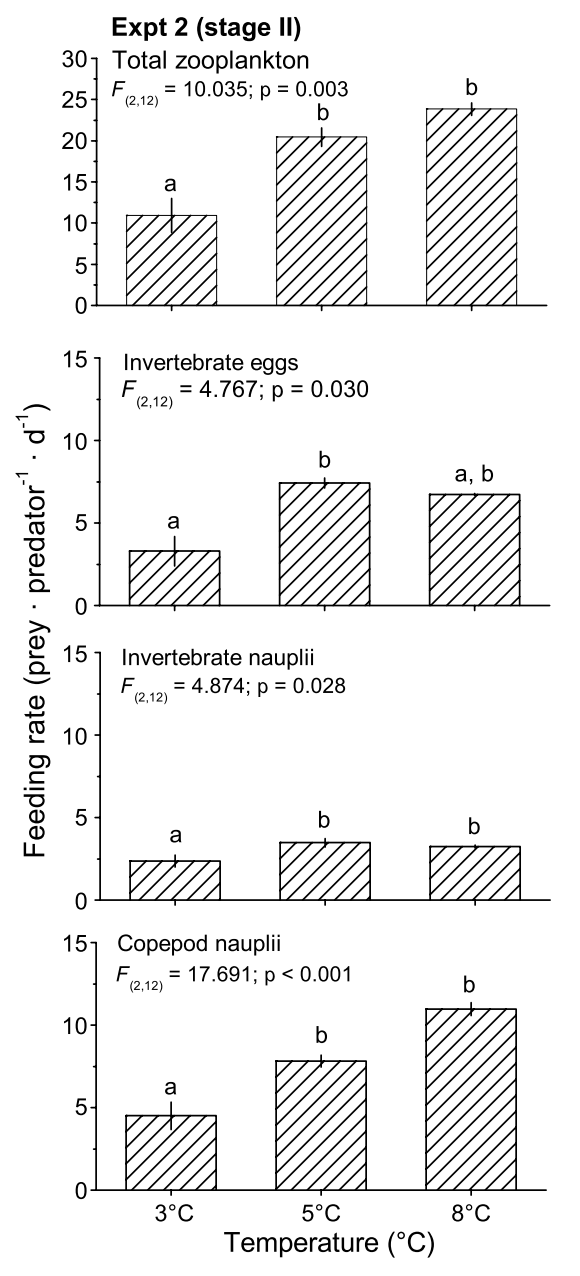

Fig. 6. Pandalus borealis. Feeding rate of Stage II shrimp larvae on natural zooplankton at 3 different temperatures. Statistical tests used were 1-way ANOVA followed by a posteriori comparisons among means by a Tukey procedure. Different letters above bars indicate significant differences. Error bars are $\pm \mathrm{SE}$

\section{Expt 4-effects of predator life stage}

According to the results of the preliminary experiments carried out to investigate the effect of experiment durations of $2,4,6$, and $24 \mathrm{~h}, 4$ and $6 \mathrm{~h}$ incubation periods gave the clearest predation signal in each larval stage (Fig. 8). Both the shortest and the longest periods of incubation seemed to be inappropriate: the $2 \mathrm{~h}$ period showed a high variability among replicates, whereas the $24 \mathrm{~h}$ period showed a large decrease in the predation rate for Stage III to VI larvae (Fig. 8). Therefore, incubation periods of 4 and $6 \mathrm{~h}$ were used to calculate the predation rate of each larval stage.

The ANOVA results show that developmental stage had a significant effect on predation rate (Fig. 9). The predation rate increased gradually from $29.5 \pm 3.1$
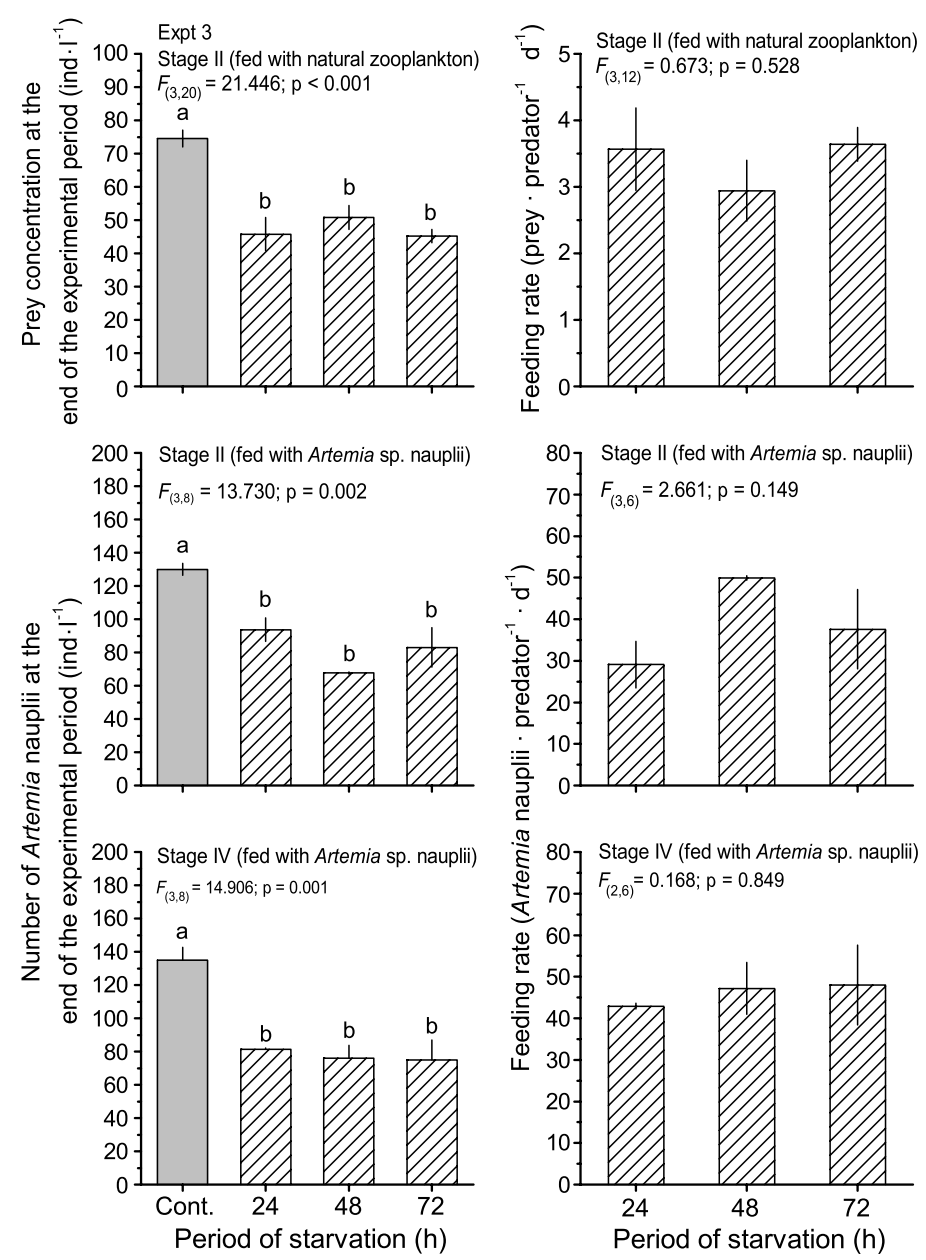

Fig. 7. Pandalus borealis. Prey concentrations (left-hand columns) and feeding rate (right-hand colums) of Stages II and IV shrimp larvae fed with natural zooplankton and freshly hatched Artemia sp. nauplii after a period of starvation of 24,48 , or $72 \mathrm{~h}$. Statistical tests used were 1-way ANOVA followed by a posteriori comparisons among means by a Tukey procedure. Different letters above bars indicate significant differences. Error bars are $\pm \mathrm{SE}$

Artemia sp. nauplii per predator $\mathrm{d}^{-1}$ at Stage I to $104.7 \pm 14.5$ Artemia sp. nauplii per predator $\mathrm{d}^{-1}$ at Stage $\mathrm{V}$, and slightly decreased to $80.9 \pm 8.0$ Artemia sp. nauplii per predator $\mathrm{d}^{-1}$ at Stage VI.

\section{DISCUSSION}

Pandalus borealis larvae are either herbivorous (Stages I and II), carnivorous (Stage III to VI), or omnivorous (Stickney \& Perkins 1981, Strathmann 1987, Rasmussen et al. 2000). However, the importance of the different food categories is not well known for the different larval stages. Rasmussen et al. (2000) reported that Stage I and II $P$. borealis larvae have higher clear- 
ance rates for algae than for other items offered (newly hatched enriched Artemia sp. and natural plankton $<250 \mu$ m diameter), while Stage III larvae lose interest in planktonic algae. Stickney \& Perkins (1981) classified $P$. borealis larvae as herbivorous. Nevertheless, they also noted that Stage I and II larvae will frequently eat animal food (remains of cirripedes, copepod nauplii, small larval polychetes, larval echinoderm spines, and copepods) when it is abundant, and this kind of food may be more important than phytoplankton as the spring season advances and the larvae get bigger (Stickney \& Perkins 1981). A recent study carried out in our laboratory (P. Ouellet pers. comm.) showed very low weight-specific trypsin activity values $\left(<5 \times 10^{-5} \mathrm{IU}_{\mu \mathrm{g}^{-1}}\right.$ dry weight $)$ in Stage I and II larvae sampled in the Gulf of St. Lawrence in spring 2002. This suggests that the northern shrimp larvae would be predominantly carnivorous in the Gulf of St. Lawrence even at young stages (see Jones et al. 1997). Therefore, we can be relatively confident in interpreting our laboratory results to natural conditions even

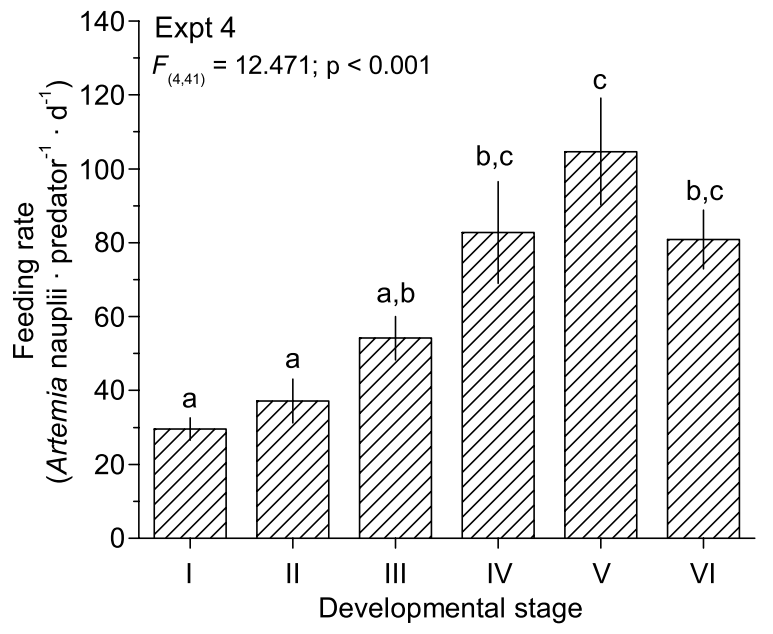

Fig. 9. Pandalus borealis. Daily feeding rates expressed in term of the number of prey eaten (Artemia sp. nauplii per predator $\mathrm{d}^{-1}$ ) measured in Stage I to VI shrimp larvae. Statistical tests used were 1-way ANOVA followed by a posteriori comparisons among means by a Tukey procedure. Different letters above bars indicate significant differences. Error bars are $\pm \mathrm{SE}$

though we have not considered phytoplankton as a potential food source in our experiments.

\section{Quantity of food uptake (Expt 1)}

Results from the functional response experiment showed that a significant predation signal was only detected at prey densities $\geq 24$ prey $\mathrm{l}^{-1}$ and that the predation rate increased significantly up to the highest prey concentration examined (250 prey $\mathrm{l}^{-1}$ ) without reaching a plateau. Therefore, it seems probable that Stage IV shrimp larvae may suffer from starvation at prey population densities $<24$ prey $\mathrm{l}^{-1}$ and cannot attain their maximal feeding capacity unless they occur in zooplankton patches denser than 250 prey $\mathrm{l}^{-1}$.

Shrimp larvae occur and develop in May and June in the Gulf of St. Lawrence and live in the surface layer, between 0 and $25 \mathrm{~m}$, during the day and the night (Ouellet \& Lefaivre 1994). Thus, we need to know the density of the zooplankton prey population in the surface layer in spring to be able to apply our laboratory results to natural conditions. The only such data available are those of St-Pierre et al. (1996), who sampled mesozooplankton $(0.5 \mathrm{~m}$ diameter) with a $73 \mu \mathrm{m}$-mesh net towed from a depth of $15 \mathrm{~m}$ to the surface over a $24 \mathrm{~h}$ period (1 net every 3 h) in late June 1989 in the north central Gulf of St. Lawrence. According to their study, the mean zooplankton density in the surface layer, including copepod eggs and early developmental stages
Fig. 8. Pandalus borealis. Daily feeding rates of Stages I to VI shrimp larvae estimated after incubations of 2, 4, 6, and $24 \mathrm{~h}$. Error bars are $\pm \mathrm{SE}$ 
(N1-C1), was 27 prey items $\mathrm{l}^{-1}$ with a maximum of 63 prey items $\mathrm{l}^{-1}$. This suggests that the natural zooplankton density observed in the field can fulfill the minimum feeding rate of the Stage IV shrimp larvae observed in our experiments. On the other hand, this result indicates that the ambient zooplankton abundances were not high enough to permit Stage IV shrimp larvae to attain their maximal feeding capacity if prey are randomly or evenly distributed. However, a small-scale patchy distribution of prey and/or turbulence in the surface layer would allow a higher food consumption rate for Stage IV shrimp larvae. The importance of food patchiness has previously been discussed and described for various marine organisms (Rose \& Leggett 1990, Noda et al. 1992, Boyd 1996). Furthermore, Saiz (1994) showed that turbulence increases the encounter rates between the calanoid copopod Acartia tonsa and its food (phytoplankton cells), and indicated that the turbulence intensity might increase food concentrations to levels comparable to satiation in environments with low food concentrations. Ouellet \& Lefaivre (1994) observed that the daytime maximum abundance of Stage I and II shrimp larvae (Pandalus borealis) coincided with subsurface chlorophyll $a$ and suspended particle concentration maxima. They suggested that the vertical distribution maintained by shrimp larvae is a mechanism to ensure maximum food availability and to optimize development time in the stratified water of Gulf of St. Lawrence. Therefore, any mechanism that concentrates the food of shrimp larvae to densities $>24$ prey $\mathrm{l}^{-1}$ and/or that increase the encounter rates between shrimp larvae and their prey will enhance feeding success and thus growth and survival.
Most previous laboratory experiments on larval feeding have been carried out using Artemia sp. nauplii or monospecific phytoplankton or zooplankton cultures as food sources (Anger 2001). Therefore, very little quantitative information exists on the uptake of natural prey species or on selective larval behavior in mixed assemblages of food organisms (Anger 2001). To our knowledge, the only available data on the feeding rate of the shrimp larvae Pandalus borealis feeding on a natural zooplankton assemblage are those of Paul et al. (1979), which were obtained from Stage I shrimp larvae. According to their results, the predation rate of Stage I shrimp larvae varied from 0.14 to 1.06 prey items per predator $\mathrm{d}^{-1}$ at 20 and 160 prey $\mathrm{l}^{-1}$, respectively. Nevertheless, it is difficult to compare these feeding rates with our results, since the zooplankton assemblage that was offered in the different experiments varied in terms of prey type, prey size, and proportion of various prey. For instance, if we compare the predation rates of the Stage IV and II larvae measured in Expts 1 and 2, respectively, we observe that for an initial prey concentration of 250 prey items $\mathrm{l}^{-1}$, predation rates varied from 11.82 prey per predator $\mathrm{d}^{-1}$ in Stage IV to 20.26 prey per predator $\mathrm{d}^{-1}$ in Stage II. Therefore, the daily predation rate would be higher in Stage II than in Stage IV. However, if we convert the predation rate into energy values (Table 1), we obtain a daily predation rate of 18.31 and $46.07 \mu \mathrm{g}$ C per predator $\mathrm{d}^{-1}$ in Stages II and IV, respectively. This difference is mostly due to the variability in the size and energy value of the prey eaten by each stage (see next section). This supports the suggestion made by Anger

Table 1. Mean number of prey of different zooplankton species eaten by Stage IV and II shrimp larvae in Expts 1 and 2, respectively. Estimated carbon content for each prey item obtained from the literature is also shown

\begin{tabular}{|c|c|c|c|c|}
\hline Prey type & $\begin{array}{l}\text { Mean number of } \\
\text { prey predator }{ }^{-1} \mathrm{~d}^{-1}\end{array}$ & $\begin{array}{l}\text { Estimated C value } \\
\left(\mu \mathrm{g} \text { ind }^{-1}\right)\end{array}$ & $\begin{array}{l}\text { Total C ingested } \\
\left(\mu \mathrm{g} \text { ind }^{-1} \mathrm{~d}^{-1}\right)\end{array}$ & Source \\
\hline \multicolumn{5}{|l|}{ Stage II (Expt 2) } \\
\hline Calanus finmarchicus CI-CIV & 0.58 & 12.07 & 7.00 & Hirche et al. (2001) \\
\hline Invertebrate eggs & 7.43 & 0.48 & 3.57 & \\
\hline Invertebrate nauplii & 3.48 & 0.5 & 1.74 & $\mathrm{~b}$ \\
\hline Oithona spp. & 0.95 & 3.12 & 2.96 & Coyle et al. (1990) \\
\hline Copepod nauplii & 7.82 & 0.39 & 3.04 & Hirche et al. (2001) \\
\hline Total & 20.26 & & 18.31 & \\
\hline \multicolumn{5}{|l|}{ Stage IV (Expt 1) } \\
\hline Copepod eggs & 2.60 & 0.23 & 0.60 & Runge \& Plourde (1996) \\
\hline Copepod nauplii & 1.06 & 0.39 & 0.41 & Hirche et al. (2001) \\
\hline Invertebrate nauplii & 0.77 & 0.5 & 0.39 & \\
\hline Oithona spp. & 0.56 & 3.12 & 1.75 & Coyle et al. (1990) \\
\hline C. finmarchicus CIII & 1.64 & 11.3 & 18.53 & Hirche et al. (2001) \\
\hline C. finmarchicus CII & 3.73 & 5.6 & 20.89 & Hirche et al. (2001) \\
\hline C. finmarchicus CI & 1.46 & 2.4 & 3.50 & Hirche et al. (2001) \\
\hline Total & 11.82 & & 46.07 & \\
\hline \multicolumn{5}{|c|}{ a Two times the $\mathrm{C}$ value of the copepod eggs $\left(0.23 \mu \mathrm{g} \mathrm{C} \mathrm{egg}{ }^{-1}\right.$; Runge \& Plourde (1996) } \\
\hline
\end{tabular}


(2001) that any comparison of the predation rate between developmental stages and/or decapod species should be made in terms of energy value instead of number of prey eaten.

\section{Prey selectivity (Expts 1 and 2)}

Results from Expts 1 and 2 showed that the majority of prey eaten by the Stage II shrimp larvae (Expt 2) were small (copepod nauplii, invertebrate eggs, and nauplii), while those eaten by the Stage IV larvae (Expt 1) were larger (Calanus finmarchicus CI, CII, CIII, and body parts of CIV, CV, CVI), although they also ate small prey (copepod eggs and nauplii, invertebrate nauplii). From these results, it is difficult to say whether shrimp of a given developmental stage have the ability to select prey of a particular size, because the proportion of small and large prey was not the same in both experiments. Nevertheless, our results support the observation made by Anger (2001) that there is selectivity for small prey in early decapod larval stages and a preference for larger prey in later stages. Furthermore, this ontogenetic change in particle size selection is not exclusive, since Stage II shrimp larvae can eat relatively large prey (Calanus finmarchicus CI to CIV), while Stage IV larvae continue to accept small prey (copepod eggs and nauplii, invertebrate nauplii).

\section{Effects of temperature (Expt 2)}

The feeding rate of northern shrimp larvae has been reported to increase with temperature (Shumway et al. 1985). In addition, Wienberg (1982) reported that twice as many Artemia sp. nauplii were ingested per day at $12^{\circ} \mathrm{C}$ than at $3^{\circ} \mathrm{C}$. Likewise, results from our experiment measuring the effect of temperature on the feeding rate of Stage II shrimp larvae showed a significant increase in feeding activity from 3 to $5^{\circ} \mathrm{C}$ but no significant change from 5 to $8^{\circ} \mathrm{C}$. P. Ouellet (pers. comm.), who studied the growth rate of different stages of Pandalus borealis at the same temperatures $\left(3,5\right.$, and $\left.8^{\circ} \mathrm{C}\right)$ fed $\mathrm{ad}$ libitum with freshly hatched Artemia sp. nauplii, observed a higher growth rate in Stage II larvae reared at 5 and $8^{\circ} \mathrm{C}$ than in those reared at $3^{\circ} \mathrm{C}$. In the Gulf of St. Lawrence, the sea-surface temperature during the first half of June, the period of higher abundance of Stage II shrimp larvae in the Gulf (Ouellet et al. 1990), varied between 2 and $7^{\circ} \mathrm{C}$ from 1990 to 2000 (P. Ouellet unpubl. data). Therefore, according to our results indicating that the maximum feeding rate of Stage II shrimp larvae fed with a natural zooplankton assemblage occurs between 5 and $8^{\circ} \mathrm{C}$, we can conclude that under natural conditions, the sea-surface temperature in June in the Lower Estuary and the Gulf of St. Lawrence would not always be optimal for a maximum feeding rate of Stage II northern shrimp larvae.

\section{Influence of starvation (Expt 3)}

Under conditions of irregular availability or permanently low food concentrations, hunger should enhance feeding activity ('maximal feeding strategy') (Anger 2001). This has been observed in some higher decapod larvae (Cronin \& Forward 1980, Chu \& Shing 1986). Nevertheless, our results on the effect of starvation did not show any enhancement of feeding activity in either Stage II larvae fed with natural zooplankton or Stages II and IV fed with Artemia sp. after 24, 48 , and $72 \mathrm{~h}$ of starvation. Another generally wellaccepted hypothesis concerning the effect of starvation is the 'optimal foraging strategy', which suggests that short periods of food deprivation may enhance the appetite and ingestion rates while longer periods of poor food availability induce energy saving mechanisms, including a reduction in feeding activity (Anger 2001). Again, our results do not permit us to detect any signal of such a mechanism in Stage II and IV larvae after 24,48 , and $72 \mathrm{~h}$ of starvation. The absence of any response in our starvation experiments could be due to the fact that the starvation periods used were too short in comparison to the length of the inter-molt period (ca. $12 \mathrm{~d}$ at $5^{\circ} \mathrm{C}$; P. Ouellet pers. comm.). This is particularly true if the larvae have passed the reserve saturation point, which is the point in larval development when sufficient nutritional reserves allow molting to the next stage, regardless of the availability of further food supplies (Anger \& Dawirs 1981).

\section{Effects of predator life stage (Expt 4)}

The exponential increase in predation rate among successive larval instars (Stages I to V) followed by a decrease in Stage VI has been observed in many higher decapod species (see review in Anger 2001). Furthermore, the decrease in predation rate observed in Stage VI may be an indication that this stage corresponds to the transition from zoeal stages to decapodids in Pandalus borealis living in the Estuary and the Gulf of St. Lawrence. Indeed, a decrease in the feeding activity of the premetamorphic stage was observed in both the spider crab Hyas araneus (Anger \& Dietrich 1984, Harms et al. 1991) and the brachyuran crab Rhithropanopeus harrisii (Levine \& Sulkin 1984), and was associated with lower ingestion rates in the premetamorphic stages due to dramatic ecological changes in morphology and behavior (Anger 2001). 
Acknowledgements. We thank J.-F. St-Pierre for his participation in the sampling of the zooplankton and L. Devine for helping to improve the quality of the text. Our sincere thanks to Drs. P. Ouellet, K. Anger, I. Bergström, and 2 anonymous referees for their comments, which were very helpful in revising the paper. This study is a contribution to the research program on growth and recruitment of northern shrimp of the Maurice Lamontagne Institute and was supported by the Canadian Department of Fisheries and Oceans Science Strategic Fund.

\section{LITERATURE CITED}

Anger K (2001) The biology of decapod crustacean larvae. In: Vonk R (ed) Crustacean issues, 14. AA Balkema, Lisse

Anger K, Dawirs RR (1981) Influence of starvation on the larval development of Hyas araneus (Decapoda, Majidae). Helgol Meeresunters 34:287-311

Anger K, Dietrich A (1984) Feeding rates and gross growth efficiencies in Hyas araneus L. larvae (Decapoda: Majidae) reared in the laboratory. J Exp Mar Biol Ecol 77: 169-181

Bergström BI (2000) The biology of Pandalus. In: Southward AJ, Tyler PA, Young CM, Fuiman L (eds) Advances in marine biology. Academic Press, London, p 55-244

Boyd IL (1996) Temporal scales of foraging in a marine predator. Ecology 72:426-434

Chu KH, Shing CK (1986) Feeding behavior of the shrimp, Metapenaeus ensis, on Artemia nauplii. Aquaculture 58:175-184

Coyle KO, Paul AJ, Ziemann DA (1990) Copepod populations during the spring bloom in an Alaskan subarctic embayment. J Plankton Res 12:759-797

Cronin TW, Forward RB (1980) The effects of starvation on phototaxis and swimming of larvae of the crab Rhithropanopeus harrisii. Biol Bull 158:283-294

Harms J, Anger K, Klaus S, Seeger B (1991) Nutritional effects on ingestion rate, digestive enzyme activity, growth, and biological composition of Hyas araneus L. (Decapoda: Majidae) larvae. J Exp Mar Biol Ecol 145:233-265

Haynes E (1979) Description of larvae of the northern shrimp, Pandalus borealis, reared in situ in Kachemak Bay, Alaska. Fish Bull 77:157-173

Hirche HJ, Brey T, Niehoff B (2001) A high-frequency time series at Ocean Weather Ship Station M (Norwegian Sea): population dynamics of Calanus finmarchicus. Mar Ecol Prog Ser 218:205-219

Jones DA, Kumlu M, Le Vay L, Fletcher DJ (1997) The digestive physiology of herbivorous, omnivorous and carnivorous crustacean larvae: a review. Aquaculture 155:285-295

Klein-Breteler WCM, Fransz HG, Gonzalez SR (1982) Growth and development of four calanoid copepod species under experimental and natural conditions. Neth J Sea Res 16: 195-207

Lebour MV (1922) The food of plankton organisms. J Mar Biol Assoc UK 12:644-677

Levine DM, Sulkin SD (1984) Nutritional significance of long-

Editorial responsibility: Otto Kinne (Editor),

Oldendorf/Luhe, Germany chain polyunsaturated fatty acids to the zeoal development of the Brachyuran crab, Eurypanopeus depressus (Smith). J Exp Mar Biol Ecol 40:247-257

Noda M, Kawabata K, Gushima K, Kakuda S (1992) Importance of zooplankton patches in foraging ecology of the planktivorous reef fish Chromis chrysurus (Pomacentridae) at Kuchinoerabu Island, Japan. Mar Ecol Prog Ser 87:251-263

Ouellet P, Lefaivre D (1994) Vertical distribution of northern shrimp (Pandalus borealis) larvae in the Gulf of St. Lawrence; implications for trophic interactions and transport. Can J Fish Aquat Sci 51:123-132

Ouellet P, Lefaivre D, Koutitonsky V (1990) Distribution of shrimp (Pandalus borealis) larvae and hydrographic pattern in the northern Gulf of St. Lawrence. Can J Fish Aquat Sci 47:2068-2078

Ouellet P, Taggart CT, Frank KT (1995) Early growth, lipid composition, and survival expectations of shrimp Pandalus borealis larvae in the northern Gulf of St. Lawrence. Mar Ecol Prog Ser 126:163-175

Paul AJ, Paul JM, Shoemaker PA, Feder HM (1979) Prey concentrations and feeding response in laboratory-reared stage-one zoeae of king crab, snow crab, and pink shrimp. Trans Am Fish Soc 108:440-443

Rasmussen T, Aschan M, Christiansen JS (2000) The implementation of laboratory studies to shrimp recruitment modelling - a brief review of experimental procedures. ICES CM 2000/R:07, p 1-16

Rose GA, Leggett WC (1990) The importance of scale to predator-prey spatial correlations: an example of Atlantic fishes. Ecology 71:33-43

Runge JA, Plourde S (1996) Fecundity characteristics of Calanus finmarchicus in coastal waters of eastern Canada. Ophelia 44:171-187

Saiz E (1994) Observations of the free-swimming behavior of Acartia tonsa: effects of food concentration and turbulent water motion. Limnol Oceanogr 39:1566-1578

Savard L, Bouchard H, Bourgdages H (2002) Estuary and Gulf of St. Lawrence shrimp (Pandalus borealis) stock assessment for the 1990-2001 period. Canadian Science Advisory Secretariat of Fisheries and Oceans, Canada, p 1-89

Shumway SE, Perkins HC, Schick DF, Stickney AP (1985) Synopsis of biological data on the pink shrimp, Pandalus borealis Krøyer, 1838. NOAA Tech Rep 144:1-57

Stickney AP, Perkins HC (1981) Observations on the food of the larvae of the northern shrimp, Pandalus borealis Krøyer (Decapoda, Caridea). Crustaceana 40:36-49

St-Pierre JF, Runge J, Joly P, de Lafontaine Y (1996) Données physiques, chimiques et biologiques sur le plancton du nord du Saint-Laurent. Partie I: juin 1989. Rapp Stat Can Sci Halieut Aquat 986:1-92

Strathmann (1987) Larval feeding. In: Giese AC, Pearse JS, Pearse VB (eds) Reproduction of marine invertebrates. Blackwell Scientific Publications, Palo Alto, CA, p 465-550

Wienberg R (1982) Studies on the influence of temperature, salinity, light, and feeding rate on laboratory reared larvae of deep sea shrimp, Pandalus borealis Krøyer 1838. Meeresforschung 29:136-153

Submitted: June 24, 2003; Accepted: October 28, 2003

Proofs received from author(s): December 18, 2003 